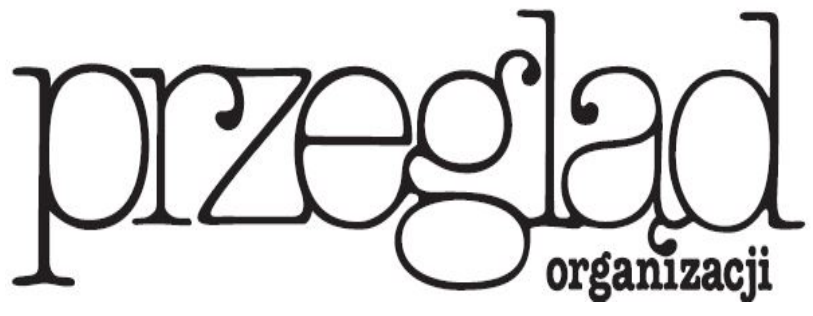

Miesięcznik TNOiK Założył Karol Adamiecki w 1926 r.

\title{
KLUCZOWE WYZWANIA I BARIERY ORAZ TRENDY W ZARZADZANIU PROJEKTAMI Z PUNKTU WIDZENIA PROJEKTÓW REALIZOWANYCH W POLSCE
}

https://doi.org/10.33141/po.2019.03.03

\section{Emil Bukłaha, Mateusz Juchniewicz}

Przegląd Organizacji, Nr 3 (950), 2019, ss. 14-20 www.przegladorganizacji.pl CTowarzystwo Naukowe Organizacji i Kierownictwa (TNOiK)

\section{Wprowadzenie}

A ktualne wyzwania $\mathrm{w}$ realizacji projektów obejmują cały szereg zagadnień o charakterze procesowym i przekrojowym. Z jednej strony związane są one z kwestiami definiowania działalności jako projektów, błędnego lub nieprecyzyjnego zrozumienia kwestii związanych z cyklem zarządzania projektami, procedurami kompleksowego wyboru przedsięwzięć do realizacji, ich definiowania, planowania, prowadzenia działań wykonawczych i powykonawczych oraz podejmowanych w tych zakresach decyzji o charakterze menedżerskim. Z drugiej - odnoszą się do

obszarów zarządzania ryzykiem, zasobami, zakresem, właściwej kontroli przedsięwzięć w stosunku do ich celów i uzasadnienia biznesowego, wreszcie organizacji struktur projektowych, angażowania interesariuszy, dojrzałości projektowej organizacji czy zarządzania wiedzą projektową. Nie mniej ważnym źródłem zagadnień wyznaczających trendy i bariery w realizacji przedsięwzięć stała się dla autorów niniejszego artykułu również idea projektyzacji i dwuzręczności jako kluczowych koncepcji identyfikujących rolę i znaczenie projektów w realizacji celów organizacji (Trocki, 
2018, s. 9-15). W ich przekonaniu powyższe koncepcje stanowią wyzwanie dla osób zarządzających organizacjami ze względu na swoją złożoność, ścisłe relacje między działalnością o charakterze operacyjnym (run the business) i projektowym (change the business), a także konieczność podejmowania działań $\mathrm{w}$ powyższych zakresach $\mathrm{w}$ stale zmieniającym się otoczeniu rynkowym.

Potraktowanie powyższych zagadnień jako źródeł wyzwań w zarządzaniu projektami stało się podstawą do zdefiniowania problemu badawczego, polegającego na identyfikacji zagadnień stanowiących zbiór najważniejszych wyzwań i barier, z jakimi muszą mierzyć się obecnie osoby zaangażowane $\mathrm{w}$ realizację projektów na różnych szczeblach decyzyjnych, a także trendów rozwojowych w zarządzaniu projektami, ocenianych przez nich jako najistotniejsze w najbliższych latach. Biorąc to pod uwagę, celem artykułu jest prezentacja wyników badań zrealizowanych w 2019 roku w przedsiębiorstwach realizujących projekty w Polsce, obejmujących powyższy zakres zagadnień. Analizę zebranych danych poprzedzono omówieniem problematyki cyklu zarządzania projektami oraz zjawisk projektyzacji i dwuzręczności organizacyjnej w zakresie pozwalającym na pełniejszą interpretację uzyskanych wyników badań.

\section{Miejsce i rola projektów w zarządzaniu}

$\mathbf{Z}$ arządzanie projektami jako obszar wiedzy w zakresie nauk stosowanych powstało przede wszystkim w odpowiedzi na potrzeby praktyki gospodarczej w sytuacji, gdy tradycyjne metody i narzędzia zarządzania okazały się niewystarczające do skutecznej realizacji dużych, złożonych i niepowtarzalnych przedsięwzięć. W ciągu kilku dekad rozwinęło się od zbioru prostych zasad i narzędzi do kompleksowej i wieloaspektowej subdyscypliny w obszarze nauk o zarządzaniu, z własnym obiektem badań, terminologią oraz podstawami teoretycznymi i metodycznymi (Lichtarski, Wąsowicz, 2017, s. 124). Naukowe podejście do zarządzania projektami znacząco rozwinęło się w okresie II wojny światowej i trwa do dzisiaj. Od tamtych lat można obserwować stały rozwój metod i koncepcji zarządzania projektami. Ma to swoje źródło m.in. w zmieniającym się otoczeniu projektów ze szczególnym uwzględnieniem zmian zachodzących $\mathrm{w}$ funkcjonowaniu przedsiębiorstw i w sposobach rozwoju nowych produktów (Spałek, 2017, s. 106).

Zarządzanie projektami pełni $\mathrm{w}$ organizacji kluczową rolę we wdrażaniu zmian, optymalizacji procesów i wprowadzaniu usprawnień, zaś projekty występują we wszystkich obszarach ludzkiej aktywności, poczynając od administracji publicznej i gospodarki, na kulturze i sporcie kończąc (Trocki, 2012, s. 15-20). Choć w literaturze przedmiotu istnieje wiele definicji projektu (Mingus, 2009; Trocki, 2012; PMBOK Guide, 2013; Wysocki, 2013), jednak niezależnie od ich pochodzenia wszystkie mają pewne elementy wspólne, które zestawione ze sobą pozwalają stworzyć poniższą definicję tego pojęcia. Projekt (przedsięwzięcie) można zdefiniować jako złożoną sekwencję logicznie uporządkowanych działań, mających określony cel i (o ile to możliwe) produkty końcowe o zdefiniowanych wymaganiach jakościowych, a także zasoby i środki potrzebne do ich osiągnięcia oraz wyznaczone ramy czasowe (początek i koniec). Projekt ma najczęściej charakter innowacyjny, niepowtarzalny, wnoszący unikatową wartość dodaną do organizacji, zaś jego realizacja jest obarczona wyższym ryzykiem niepowodzenia niż wykonywanie działań o charakterze procesowym (powtarzalnym). Realizacja projektów jest zwykle rozciągnięta $\mathrm{w}$ czasie, wymaga zaangażowania znacznych, lecz limitowanych środków i zasobów, opiera się na pracy zespołowej wyspecjalizowanych wykonawców i może być związana $\mathrm{z}$ wysokim ryzykiem technicznym, organizacyjnym, ekonomicznym oraz prestiżowym (Mingus, 2009; Trocki, 2012; PMBOK Guide, 2013; Wysocki, 2013; Zandhuis, Stellingwerf, 2013). Powyższe cechy stanowią między innymi o powodach istnienia szerokiego zakresu wyzwań w zarządzaniu projektami.

Modelowe przedstawienie przebiegu etapów zarządczych projektu $\mathrm{z}$ uwzględnieniem procesu podejmowania decyzji w każdej jego fazie opisuje zagadnienie cyklu zarządzania projektem. Choć koncepcja ta opiera się na założeniu, że pomimo rozbieżnych celów, wielkości i sposobów realizacji projektów można określić wspólny dla nich wszystkich zestaw procesów zarządczych, to w literaturze przedmiotu nie istnieje jeden, powszechnie akceptowany cykl zarządzania projektami. Aby zobrazować stopień zróżnicowania tej problematyki, $w$ tabeli 1 zestawiono wybrane sposoby definiowania tego cyklu ${ }^{1}$.

Tabela 1. Wybrane sposoby podziału cyklu zarządzania projektem

\begin{tabular}{|c|l|l|l|l|l|l|}
\hline Rok & $\begin{array}{r}\text { Autor/ } \\
\text { Koncepcja }\end{array}$ & \multicolumn{5}{|c|}{ Elementy cyklu } \\
\hline 2004 & Standard PCM & Programowanie & Identyfikacja & Formułowanie & $\begin{array}{l}\text { Wdrażanie } \\
\text { i monitorowanie }\end{array}$ & Ewaluacja i audyt \\
\hline 2004 & Z. Szyjewski & $\begin{array}{l}\text { Specyfikacja } \\
\text { wymagan }\end{array}$ & Projektowanie & Implementacja & Testowanie & $\begin{array}{l}\text { Wdrożenie } \\
\text { i pielęgnacja }\end{array}$ \\
\hline 2012 & Norma ISO 21500 & Inicjowanie & Planowanie & Realizacja & Kontrolowanie & Zamykanie \\
\hline 2012 & M. Trocki & Inicjowanie & Definiowanie & Planowanie & Wykonawstwo & Zakończenie \\
\hline 2013 & Standard PMBoK & Inicjowanie & Planowanie & Realizacja & $\begin{array}{l}\text { Monitorowanie } \\
\text { i kontrola }\end{array}$ & $\begin{array}{l}\text { Zakończenie } \\
\text { (zamknięcie) }\end{array}$ \\
\hline
\end{tabular}

Źródto: opracowanie własne na podstawie: Bukłaha, 2019, s. 49 
Biorąc powyższe zestawienie pod uwagę, można zauważyć, że pomimo różnic w pochodzeniu konkretnych koncepcji opisują one w zasadzie te same etapy cyklu: wstępne (inicjowanie i definiowanie), planistyczne (formułowanie i planowanie), wykonawcze (realizowanie, wdrażanie, implementacja i wykonawstwo), kontrolne (kontrolowanie, monitorowanie, testowanie) i fazę zamknięcia projektu (zamykanie, zakończenie). Nazwy oraz liczba etapów w każdym cyklu wynikają m.in. z potrzeb kontrolnych i nadzorczych pochodzących od zespołów wykonawczych, organizacji zlecających projekt oraz kluczowych interesariuszy zaangażowanych w jego realizację, a także specyfiki i wielkości przedsięwzięcia oraz branży i dziedziny gospodarki, której dotyczy. Daje to dobry obraz ścierających się koncepcji z tego zakresu, co z jednej strony może zwiększać chaos terminologiczny utrudniający wyłonienie się jednej uznanej koncepcji podziału procesu zarządzania projektami na etapy, a $\mathrm{z}$ drugiej strony wskazuje na mnogość podejść, jakie można zastosować $\mathrm{w}$ obszarze zarządczym realizacji projektów. Z tego powodu w przekonaniu autorów ta problematyka stanowi kolejne istotne źródło wyzwań związanych z realizacją projektów.

\section{Dwuzręczność i projektyzacja na poziomie organizacji}

B iorąc pod uwagę główne sposoby działalności organizacji, jej aktywność można podzielić na dwie kategorie: działania operacyjne (procesowe, rutynowe) i projektowe (innowacje, zmiany, transformacje). Zjawisko zdolności organizacji do znalezienia równowagi między działalnością powtarzalną a projektową zyskało w literaturze przedmiotu nazwę dwuzręczności (ambidexterity) (Zakrzewska-Bielawska, 2016, s. 435-449; O’Reilly, Tushman, 2004, s. 74-81; Czakon, 2012, s. 7-10; Trocki, 2018, s. 21). Od wydajności procesów i skuteczności realizacji projektów zależy wynik finansowy, wzrost wartości czy stopień osiągnięcia celów strategicznych organizacji. O ile działalność powtarzalna zapewnia ciągłość jej działania, o tyle realizacja przedsięwzięć pozwala na jej transformację. Operacje obejmują powtarzalne czynności (run-the-business), takie jak wytwarzanie, serwis i produkcja, podczas gdy projekty dotyczą niepowtarzalnych, pojedynczych inicjatyw (change-the-business), takich jak wdrażanie nowych produktów, ulepszanie istniejących usług czy inwestowanie w infrastrukturę firmy, których przykładami są właśnie projekty. Zależność ta została przedstawiona na rysunku 1.

Propozycje usprawnień, zmiany technologii, rozwoju nowych produktów mogą wynikać z obserwacji działalności operacyjnej. Z kolei działalność transformacyjna ma za zadanie zmieniać sposób prowadzenia organizacji tak, by podnieść efektywność działań operacyjnych. Skuteczność w realizacji celów strategicznych organizacji, zdolność do działania $w$ długim okresie są więc uwarunkowane sprawnością zarówno $\mathrm{w}$ działalności operacyjnej, jak i w coraz większym stopniu transformacyjnej (Juchniewicz, 2017, s. 7).

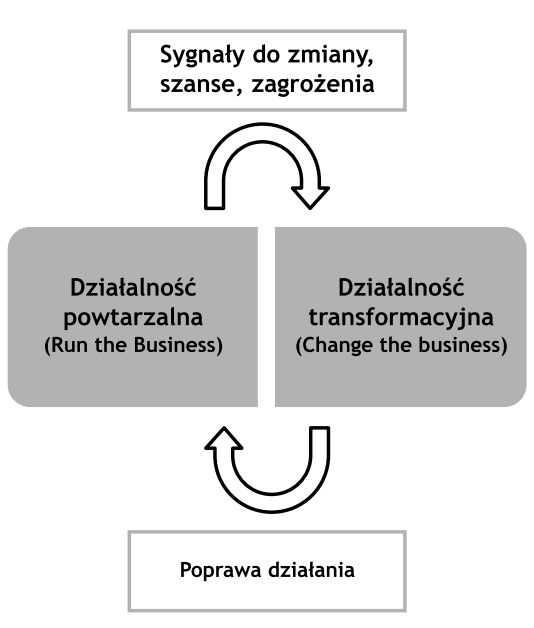

Rys. 1. Zależność między dziatalnością operacyjną i transformacyjną

Źródło: Juchniewicz, 2017, s. 6

Przy dużych wymaganiach dotyczących rozwoju i innowacji udział operacji w większości organizacji zmniejsza się, a udział projektów rośnie. Ten trend dał się zaobserwować na początku XX wieku i jest coraz wyraźniejszy w prawie każdej organizacji oraz branży: nie tylko cykle życia stały się krótsze, lecz także klienci wymagają obecnie coraz większej różnorodności i możliwości wyboru, zmuszając firmy do oferowania większej liczby produktów na prawie każdym rynku (Shenhar, Dvir, 2008, s. 3). W tym ujęciu jako podstawę do ilości i rodzajów wyzwań stojących przed kierownikami projektów można zaliczyć m.in. takie trendy, jak: rosnąca skala i złożoność problemów zarządzania, wysoka dynamika zmian otoczenia i warunków działania, rosnące potrzeby innowacyjnych rozwiązań problemów zarządzania, interdyscyplinarność wyzwań stojących przed organizacjami i wynikające $\mathrm{z}$ tego problemy komunikacyjne i koordynacyjne oraz istotne znaczenie skutecznej realizacji przedsięwzięć dla pozycji konkurencyjnej przedsiębiorstwa.

W obliczu coraz szybszych zmian oczekiwań klientów, konieczności ciągłej zmiany modelu biznesowego organizacje stają przed dylematem, w jaki sposób zapewnić ciągłość działania. W ciągu ostatnich kilkudziesięciu lat można zaobserwować trwałą ewolucję modeli biznesowych w kierunku zarządzania przez projekty. Wzrost znaczenia projektów dla organizacji, a co za tym idzie - dla gospodarki, zainspirował z jednej strony rozwój narzędzi, wytycznych i metodyk zarządzania projektami, a z drugiej spowodował skierowanie uwagi na samo zjawisko, określane mianem projektyzacji (inaczej: projektyfikacji, ang. projectification), opisanej po raz pierwszy w 1995 roku przez Ch. Midlera (1995, s. 363-375). Pierwotnie oznaczała rosnący i stabilny trend znaczenia projektów w działalności organizacji, w późniejszym okresie skutkujący również zmianami $\mathrm{w}$ systemach zarządzania, strukturze organizacyjnej oraz metodach pomiaru efektywności jej działania. W pierwszej fazie projektyzacji organizacja skupia się na sprawnym zarząazaniu pojedynczymi projektami. Pojawia się świadomość ich znaczenia dla organizacji. W kolejnym stadium zarządzanie projektami stanowi kluczowy obszar 
zarządzania całą organizacją. Wdrażane są mechanizmy zarządzania wieloma projektami. Ostatnie stadium to sytuacja, gdy projekty stanowią podstawową formę działania organizacji (Juchniewicz, 2017, s. 7). Inne systemy zarządzania są podporządkowane realizacji projektów, zaś istotny nacisk kładzie się na rozwój kompetencji w obszarze zarządzania pojedynczymi, jak też wieloma projektami realizowanymi równocześnie.

Dzięki projektyzacji organizacje łatwiej dostosowują się do zmian w otoczeniu i do wymagań klientów oraz stają się bardziej innowacyjne (Trocki, 2018, s. 10-12). Z drugiej strony to zjawisko generuje nowe wyzwania o charakterze społecznym, szczególnie w zakresie sposobów pracy, rozwoju kariery i stabilności zatrudnienia. W efekcie zmusza to ustawodawców do dopasowania prawa pracy, przedsiębiorców do innego niż obecnie planowania produkcji i organizacji pracy podległych im osób, zaś pracowników do wyboru nowych, długofalowych ścieżek rozwoju zawodowego. Stanowi to kolejne źródło wyzwań w zakresie zarządzania projektami, które będzie podstawą odniesienia do omówienia wyników badań uzyskanych przez autorów.

\section{Badania empiryczne w zakresie wyzwań, trendów i barier dla zarządzania projektami w organizacjach w Polsce}

\section{Metoda badawcza}

G łównym celem badania było sondażowe określenie głównych wyzwań, trendów i barier dla zarządzania projektami w opinii osób zaangażowanych w projekty na różnych szczeblach zarządzania. Uzyskane wyniki mogą stanowić wstęp do pogłębionych badań jakościowych.

Badania zrealizowano w 2019 r. Rozdysponowano 140 ankiet, zebrano 60 prawidłowo wypełnionych kwestionariuszy. A zatem zwrotność wyniosła prawie 43\%, co można uznać za dobry wynik. $Z$ pewnością częściowo na wysoką zwrotność wpłynął fakt bezpośredniego kontaktu respondentów z przeprowadzającymi badania

\section{Charakterystyka próby badawczej}

W badaniu wzięły udział osoby zaangażowane w projekty na różnych stanowiskach. W tabeli 2 przedstawiono zestawienie funkcji pełnionych przez respondentów. Ze względu na trudność w zdefiniowaniu populacji badawczej niemożliwy był dobór próby losowej lub quasi-losowej. Zdecydowano się przeprowadzić badania $\mathrm{z}$ doborem celowym. Polegało to na wyborze do badania organizacji realizujących projekty, a w ramach tych organizacji - osób zaangażowanych $\mathrm{w}$ proces zarządzania projektami na różnych poziomach decyzyjnych.

Zdecydowana większość, prawie 40\% respondentów pracuje w charakterze kierowników projektów, zaś 6,7\% reprezentowało kierownictwo wyższego szczebla, jednocześnie zdecydowana większość respondentów (75\%) była bezpośrednio zaangażowana w projekt - jako kierownik projektu, członek zespołu lub specjalista/ekspert/doradca.

W tabeli 3 przedstawiono sektory działalności organizacji, w których zatrudnieni byli respondenci.
Tabela 2. Funkcje petnione przez respondentów

\begin{tabular}{|l|c|c|}
\hline \multicolumn{1}{|c|}{ Funkcja } & Częstość & Procent \\
\hline Kierownik projektu & 23 & $38,3 \%$ \\
\hline Członek zespołu projektowego & 11 & $18,3 \%$ \\
\hline Specjalista/ekspert/doradca & 11 & $18,3 \%$ \\
\hline $\begin{array}{l}\text { Kierownictwo średniego } \\
\text { szczebla }\end{array}$ & 6 & $10,0 \%$ \\
\hline Kierownictwo organizacji & 4 & $6,7 \%$ \\
\hline Personel wykonawczy & 4 & $6,7 \%$ \\
\hline Inne & 1 & $1,7 \%$ \\
\hline Ogółem & 60 & $100,0 \%$ \\
\hline
\end{tabular}

Źródło: opracowanie wtasne

Tabela 3. Sektor działalności organizacji

\begin{tabular}{|l|c|c|}
\hline \multicolumn{1}{|c|}{ Sektor } & Częstość & Procent \\
\hline Inne & 20 & $33,3 \%$ \\
\hline Usługi dla ludności & 6 & $10,0 \%$ \\
\hline Budownictwo ogólne & 5 & $8,3 \%$ \\
\hline Produkcja i dystrybucja energii & 4 & $6,7 \%$ \\
\hline Transport i logistyka & 3 & $5,0 \%$ \\
\hline Organizacja pozarządowa & 3 & $5,0 \%$ \\
\hline Motoryzacja & 3 & $5,0 \%$ \\
\hline Konsulting & 3 & $5,0 \%$ \\
\hline IT & 3 & $5,0 \%$ \\
\hline Budownictwo przemysłowe & 3 & $5,0 \%$ \\
\hline Usługi finansowe & 2 & $3,3 \%$ \\
\hline Przemysł maszynowy & 2 & $3,3 \%$ \\
\hline Farmaceutyczny & 2 & $3,3 \%$ \\
\hline Telekomunikacja & 1 & $1,7 \%$ \\
\hline Ogółem & $200,0 \%$ \\
\hline
\end{tabular}

Źródto: opracowanie wtasne

Następnie poproszono respondentów o oszacowanie, jaki procent czasu pracy poświęcają na pracę $\mathrm{w}$ projektach. Zestawienie odpowiedzi zaprezentowano na rysunku 1.

Jedna czwarta respondentów szacuje (15 osób), że ponad $90 \%$ ich czasu pracy zajmują projekty. Z kolei połowa respondentów spędza nad projektami ponad $70 \%$ czasu pracy. Wskazuje to na wysoki poziom projektyzacji na poziomie jednostki. 


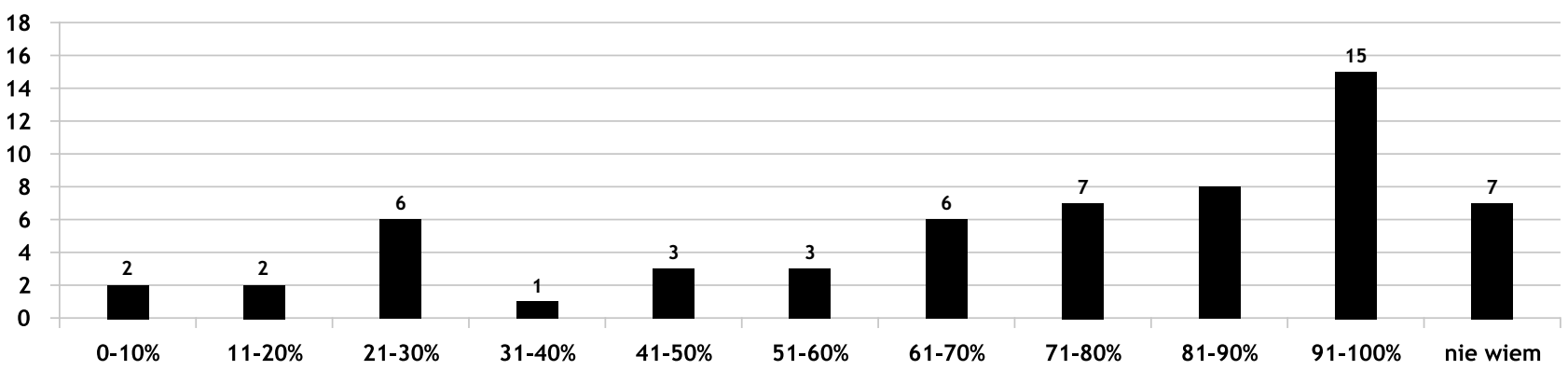

Rys. 2. Odsetek czasu poświęcany na pracę w projektach Źródło: opracowanie wtasne

Odpowiedzi na pytania o szacowany odsetek przychodów generowanych $\mathrm{w}$ organizacji przez projekty nie dały satysfakcjonujących wyników. Ponad połowa (32 z 60) respondentów nie była w stanie wskazać tych szacunków. $\mathrm{Z}$ drugiej strony - $20 \%$ respondentów oszacowało, że ich organizacje czerpią ponad $90 \%$ przychodów z projektów.

\section{Wyniki badań}

W ramach wywiadów poproszono respondentów o wskazanie trzech zagadnień:

- Największe wyzwania w pracy kierownika projektu.

- Kluczowe trendy rozwojowe zarządzania projektami.

- Kluczowe bariery dla rozwoju zarządzania projektami.

$\mathrm{W}$ kwestionariuszu zaproponowano respondentom listę odpowiedzi oraz pole do wpisywania własnych propozycji. Listę odpowiedzi opracowano na podstawie przeglądu literatury (Gemuenden, Shoper, 2015; Bredillet, 2006; Crawford i in., 2006; Kloppenborg, Opfer, 2002; Gemunden, Schoper, 2015)

Syntetyczne wyniki przedstawiono w tabelach 4-6.

Tabela 4. Największe wyzwania w pracy kierowników projektów

\begin{tabular}{|l|c|c|}
\hline \multicolumn{1}{|c|}{ Wyzwanie } & Częstość & Procent \\
\hline Dotrzymanie terminów & 16 & $26,7 \%$ \\
\hline $\begin{array}{l}\text { Zaspokojenie oczekiwań } \\
\text { interesariuszy }\end{array}$ & 8 & $13,3 \%$ \\
\hline $\begin{array}{l}\text { Motywowanie członków } \\
\text { zespołów projektowych do } \\
\text { efektywnej pracy }\end{array}$ & 8 & $13,3 \%$ \\
\hline $\begin{array}{l}\text { Osiągnięcie założonych } \\
\text { parametrów jakościowych } \\
\text { produktów projektu }\end{array}$ & 7 & $11,7 \%$ \\
\hline $\begin{array}{l}\text { Sprawne zarządzanie ryzykiem } \\
\text { projektu }\end{array}$ & 5 & $8,3 \%$ \\
\hline $\begin{array}{l}\text { Przygotowanie wiarygodnych } \\
\text { planów }\end{array}$ & 5 & $8,3 \%$ \\
\hline Dotrzymanie budżetu & 2 & $6,7 \%$ \\
\hline $\begin{array}{l}\text { Zapewnienie sprawnej } \\
\text { komunikacji w zespole }\end{array}$ & 60 & $100,0 \%$ \\
\hline Inne & & $3,3 \%$ \\
\hline Ogółem & 5 & \\
\hline
\end{tabular}

Źródto: opracowanie wtasne
Z uzyskanych danych wynika, że najważniejszym wyzwaniem dla badanych kierowników projektów było dotrzymanie założonych terminów realizacji projektu. Jednocześnie dotrzymanie budżetu zostało wskazane jedynie przez 5 osób. Wobec dość popularnych w dyskusjach o zarządzaniu projektami stwierdzeń o problemach w komunikacji nieco zaskakuje wskazanie tego zagadnienia jako wyzwania jedynie przez 4 osoby z 60 ankietowanych. W ramach wywiadów respondenci wskazali również inne zagadnienia, niewymienione $\mathrm{w}$ ankiecie:

- Dobór właściwych, kompetentnych osób do zespołu. - Adekwatne oddelegowanie do prac projektowych (odjęcie bieżących obowiązków).

Kolejne pytanie dotyczyło głównych trendów w rozwoju zarządzania projektami. Wskazania respondentów przedstawiono w tabeli 5. Każda osoba biorąca udział w badaniu mogła wskazać maksymalnie trzy trendy.

Tabela 5. Gtówne trendy w rozwoju zarządzania projektami

\begin{tabular}{|c|c|c|c|}
\hline Lp. & Zagadnienie & Częstość & Procent \\
\hline 1 & $\begin{array}{l}\text { Wsparcie pracy zespołów } \\
\text { projektowych przez rozwiązania } \\
\text { takie jak AI, VR }\end{array}$ & 27 & $20,30 \%$ \\
\hline 2 & $\begin{array}{l}\text { Rozwój projektów } \\
\text { międzynarodowych }\end{array}$ & 24 & $18,05 \%$ \\
\hline 3 & $\begin{array}{l}\text { Rozwój narzędzi IT } \\
\text { wspierających pracę } \\
\text { kierowników projektów }\end{array}$ & 21 & $15,79 \%$ \\
\hline 4 & $\begin{array}{l}\text { Wzrost znaczenia } \\
\text { niepieniężnych narzędzi } \\
\text { motywacji }\end{array}$ & 20 & $15,04 \%$ \\
\hline 5 & $\begin{array}{l}\text { Wzrost znaczenia zagadnień } \\
\text { zrównoważonego rozwoju } \\
\text { i społecznej odpowiedzialności } \\
\text { w projektach }\end{array}$ & 18 & $13,53 \%$ \\
\hline 6 & Rozwój podejścia Agile & 14 & $10,53 \%$ \\
\hline 7 & $\begin{array}{l}\text { Wzrost znaczenia tzw. } \\
\text { megaprojektów }\end{array}$ & 6 & $4,51 \%$ \\
\hline 8 & $\begin{array}{l}\text { Wzrost znaczenia } \\
\text { międzynarodowych, uznanych } \\
\text { certyfikatów fachowych }\end{array}$ & 2 & $1,50 \%$ \\
\hline 9 & Inne & 1 & $0,75 \%$ \\
\hline
\end{tabular}

Źródło: opracowanie wtasne 
Niemal połowa respondentów wskazała na spodziewany rozwój wsparcia kierowników projektów przez rozwiązania takie jak sztuczna inteligencja i wirtualna rzeczywistość. Wyniki te okazały się mocno skorelowane ze wskazaniem „rozwój narzędzi IT wspierających pracę kierowników projektów (21 wskazań). Co ciekawe, jedynie 14 osób wskazało rozwój znaczenia podejścia Agile w zarządzaniu projektami. Może to oznaczać stopniowy spadek „fascynacji” podejściem zwinnym, obserwowanej przez ostatnie lata w środowisku zarządzania projektami. Na uwagę zasługują wskazania na miejscach 4 . i 5 . Pierwsze $z$ nich to „Wzrost znaczenia niepieniężnych narzędzi motywacji”. Wśród proponowanych rozwiązań pojawiają się np. elastyczny czas pracy, możliwość rozwoju kompetencji, możliwość pracy w środowisku międzynarodowym, praca $\mathrm{w}$ projekcie bez wychodzenia $\mathrm{z}$ domu. Wpisuje się to w globalne trendy dotyczące zmiany modelu zatrudnienia $\mathrm{w}$ wielu sektorach gospodarki. Zagadnienie 5, które wskazało 18 osób, dotyczy zrównoważonego rozwoju i społecznej odpowiedzialności działalności projektowej. W obliczu globalnych wyzwań stojących przed naszą cywilizacją również kierownicy projektów będą w coraz większym stopniu uwzględniać te kwestie w swojej pracy. Niestety, tematy te są wciąż słabo rozwinięte $\mathrm{w}$ Polsce. Potwierdziły to badania zrealizowane przez zespół badawczy (Trocki, 2019) w latach 2017-2018 na podstawie modelu P5 autorstwa Global Project Management.

Ostatnie pytanie dotyczyło głównych barier w rozwoju podejścia projektowego w organizacji. Podobnie jak w przypadku poprzedniego pytania, respondenci mogli wskazać maksymalnie trzy odpowiedzi (tab. 6).

Tabela 6. Główne bariery w rozwoju podejścia projektowego w organizacji

\begin{tabular}{|l|c|c|}
\hline \multicolumn{1}{|c|}{ Zagadnienie } & Częstość & Procent \\
\hline $\begin{array}{l}\text { Brak/niespójne wsparcie kierownictwa } \\
\text { najwyższego szczebla }\end{array}$ & 36 & $29,27 \%$ \\
\hline $\begin{array}{l}\text { Kultura organizacji nie sprzyja podejściu } \\
\text { projektowemu }\end{array}$ & 27 & $21,95 \%$ \\
\hline $\begin{array}{l}\text { Brak zasobów/środków na rozwój } \\
\text { zarządzania projektami }\end{array}$ & 18 & $14,63 \%$ \\
\hline $\begin{array}{l}\text { Przekonanie, że podejście projektowe } \\
\text { w organizacji nie jest potrzebne }\end{array}$ & 16 & $13,01 \%$ \\
\hline $\begin{array}{l}\text { Przekonanie, że podejście projektowe } \\
\text { nie działa/nie przynosi spodziewanych } \\
\text { korzyści }\end{array}$ & 15 & $12,20 \%$ \\
\hline $\begin{array}{l}\text { Przekonanie, że zarządzanie projektami } \\
\text { w organizacji działa sprawnie }\end{array}$ & 9 & $7,32 \%$ \\
\hline Inne & 2 & $1,63 \%$ \\
\hline
\end{tabular}

Źródto: opracowanie własne

Przedstawione wyniki wskazują, że w badanych organizacjach istnieją poważne bariery rozwoju podejścia projektowego. Przede wszystkim to brak wsparcia kierownictwa wyższego szczebla (wskazana przez aż $60 \%$ respondentów). Z kolei niemal połowa respondentów wskazuje, że kultura organizacji nie sprzyja podejściu projektowemu. Usunięcie tych dwóch barier wymaga długofalowych inicjatyw, których ryzyko niepowodzenia jest znaczne. W obliczu opisanych we wcześniejszych częściach artykułu zagadnień dotyczących projektyzacji działalności, interesujący jest fakt, że 16 respondentów wskazało, że w ich organizacji panuje przekonanie, że podejście projektowe nie jest potrzebne.

\section{Podsumowanie}

W obliczu wzrostu znaczenia projektów w działalności zarówno pojedynczych organizacji, jak i całych sektorów i gospodarek, zmianie będą ulegały modele zarządzania i stosowane narzędzia. Zarządzanie projektami również przechodzi istotne zmiany. Po okresie rozwoju instrumentalnego, późniejszej fazy rozwoju zagadnień instytucjonalnych i personalnych, a ostatnio podejścia sytuacyjnego i zwinnego obecnie coraz częściej podejmuje się próby nakreślenia nowej fazy rozwoju. Wśród głównych trendów wskazuje się tematy związane ze zrównoważonym rozwojem $\mathrm{z}$ jednej strony i postępującą informatyzacją, wirtualizacją i automatyzacją z drugiej.

Uzyskane wyniki pozwoliły w sposób sondażowy określić główne wyzwania, z którymi muszą zmierzyć się kierownicy projektów, spodziewane trendy rozwojowe zarządzania projektami i bariery w rozwoju podejścia projektowego w organizacji.

Obecnie w sposób naturalny wskazuje się na rozwój narzędzi IT, które wspierają pracę w niemal każdej dziedzinie ludzkiej aktywności. Coraz mocniej akcentowane są zagadnienia zrównoważonego rozwoju i społecznej odpowiedzialności działalności projektowej. Wydaje się, że po fali zainteresowania podejściem Agile, koncepcja ta nieco traci na znaczeniu. Z kolei niepokojące są wyniki dotyczące głównych barier w rozwoju podejścia projektowego $\mathrm{w}$ organizacjach. Wciąż jest niska świadomość potrzeby rozwijania tego obszaru wśród kierownictwa wyższego szczebla. W opinii autorów, koresponduje to $\mathrm{z}$ badaniami dojrzałości projektowej prowadzonymi w Katedrze Zarządzania Projektami SGH w Warszawie od 2009 r. (Wyrozębski i in., 2012), które niezmiennie wskazują na niską dojrzałość organizacji w Polsce.

Przeprowadzone badania stanowią wstęp do szerszego programu badawczego. Autorzy planują zwiększenie liczebności próby badawczej, uzupełnienie badań ilościowych jakościowymi, prowadzenie badań w określonych sektorach/branżach.

\author{
dr Emil Bukłaha \\ Szkoła Główna Handlowa w Warszawie \\ Kolegium Zarządzania i Finansów \\ ORCID: 0000-0002-5271-7885 \\ e-mail: ebukla@sgh.waw.pl
}




\section{dr Mateusz Juchniewicz \\ Szkoła Główna Handlowa w Warszawie \\ Kolegium Zarządzania i Finansów \\ ORCID: 0000-0002-3598-2679 \\ e-mail: Mateusz.juchniewicz@sgh.waw.pl}

\section{Przypis}

1) Należy zaznaczyć, że cykl zarządzania projektem różni się od cyklu życia projektu. Ten pierwszy stanowi modelowe przedstawienie przebiegu procesów zarządczych projektu, uwzględniający procesy decyzyjne w każdej jego fazie, natomiast drugi jest uogólnionym przedstawieniem przebiegu wyłącznie procesów wykonawczych projektu w czasie, określającym zróżnicowanie sytuacji występujących w trakcie jego realizacji (Trocki, 2012, s. 68-74).

\section{Bibliografia}

[1] A Guide to Project Management Body of Knowledge (PMBOK Guide), $5^{\text {th }}$ Edition (2013), wydanie polskie, MTDC, Warszawa.

[2] Bredillet C.N. (2006), The Future of Project Management: Mapping the Dynamics of Project Management Field in Action, [in:] D.I. Cleland, R. Gareis (eds.), Global Project Management Handbook, 2nd Edition, McGraw-Hill, New York, pp. 3-1-3-24.

[3] Bukłaha E. (2019), Menedżerski controlling projektów - koncepcje $i$ wyniki badań, Oficyna Wydawnicza SGH w Warszawie, Warszawa.

[4] Crawford L., Pollack J., England D. (2006), Uncovering the Trends in Project Management: Journal Emphasis over the Last 10 Years, „International Journal of Project Management, Vol. 24, pp. 175-184.

[5] Czakon W. (2012), Równowaga a wzrost-relacja odwróconego $U$ w naukach o zarządzaniu, „Przegląd Organizacji”, Nr 10, s. 7-10.

[6] Gemuenden H., Schoper Y. (2015), Future Trends in Project Management, Survey Report

[7] Juchniewicz M. (2017), Model doskonalenia w zarządzaniu projektami - klasyfikacja koncepcji, „Ekonomika i Organizacja Przedsiębiorstwa”, Nr 10, s. 6.

[8] Kloppenborg T., Opfer W. (2002) The Current State of Project Management Research: Trends, Interpretation and Predictions, „Project Management Journal”, Vol. 33(2), pp. 5-18.

[9] Knoepfel H., Martinez-Almela J. (eds.), (2016) Future Trends in Project, Programme and Portfolio Management 2016, Proceedings IPMA Expert Seminar 2016.

[10] Lichtarski J.M., Wąsowicz M. (2017), Zarządzanie projektami - stan i perspektywy rozwoju subdyscypliny, [w:] K. Jędralska, W. Dyduch (red.), Prace Naukowe UE w Katowicach. Nauki o zarzadzaniu: dokonania, trendy, wyzwania, Wyd. Uniwersytetu Ekonomicznego, Katowice, s. 124-136.

[11] Midler Ch. (1995), "Projectification” of the Firm: The Renault Case, „Scandinavian Journal of Management”, No. 11, pp. 363-375.

[12] Mingus N. (2009), Zarządzanie projektami, Helion, Gliwice.
[13] O’Reilly C.A., Tushman M.L. (2004), The Ambidextrous Organization, „Harvard Business Review”, Vol. 82, No. 4, pp. 74-81.

[14] Shenhar A.J., Dvir D. (2008), Nowe spojrzenie na zarzadzanie projektami, APN Promise, Warszawa.

[15] Trocki M. (2012), Nowoczesne zarządzanie projektami, PWE, Warszawa.

[16] Trocki M. (2018), Project governance - ksztattowanie ładu projektowego organizacji, „Studia i Prace KZiF SGH”, Nr 159, s. 9-23.

[17] Trocki M. (red.), (2019), Społeczna odpowiedzialność działalności projektowej, Oficyna Wydawnicza SGH, Warszawa.

[18] Spałek S. (2017), Zarzadzanie projektami w erze przemysłu 4.0, „Ekonomika i Organizacja Przedsiębiorstwa”, Nr 9, s. 106-112.

[19] Wyrozębski P., Juchniewicz M., Metelski W. (2012), Wiedza, dojrzałość, ryzyko w zarządzaniu projektami. Wyniki badań, Oficyna Wydawnicza SGH, Warszawa.

[20] Wysocki R.K. (2013), Efektywne zarządzanie projektami, Onepress, Gliwice.

[21] Zakrzewska-Bielawska A. (2016), Paradoks eksploracji i eksploatacji - ambidexterity w zarzadzaniu strategicznym, Prace Naukowe UE we Wrocławiu, Nr 420, s. 435-449.

[22] Zandhuis A., Stellingwerf R. (2013), ISO 21500. Guidance on Project Management, Van Haren Publishing, Hertogenbosch NL.

\section{Key Challenges and Barriers and Trends in Project Management from the Point of View of Projects Implemented in Poland}

\section{Summary}

In recent years, projects have become an important part of the activities in almost every organisation. Some authors have even developed new terms describing the growing importance of projects - i.e. projectification. Hence, organizations face the challenge of the so-called ambidexterity - the ability to manage both repeatable (process) as well unique (project) activities efficiently. In the face of these interesting challenges, the authors decided to conduct a survey aimed at identifying most important challenges, trends and barriers in project management. The aim of the article is to present the results of the research carried out in year 2019 in enterprises implementing projects in Poland, covering the abovementioned range of issues. First, the authors defined the phenomenon of projectification and ambidexterity. Then, synthetic results of research on a group of 60 persons involved in projects in organizations operating in Poland have been presented and discussed. The article finishes with a summary in which potential directions for further research in the abovementioned field have been indicated.

\section{Keywords}

project, project management, projectification, ambidexterity 